\title{
The use of mixed methods to identify typology of poverty in East Java, Indonesia
}

\section{Penggunaan mixed methods untuk identifikasi tipologi kemiskinan di Jawa Timur, Indonesia}

\author{
Doddy Sumbodo Singgih ${ }^{\bowtie}$, Sudarso, \& Siti Mas’udah \\ Department of Sociology, Faculty of Social and Political Sciences, Universitas Airlangga \\ Surabaya, 60286, Jawa Timur, Indonesia \\ E-mail of corresponding author: doddy.singgih@ fisip.unair.ac.id
}

\begin{abstract}
This article describes the results of concurrent mixed method testing to identify the typology of poverty in one particular area in East Java, Indonesia known as the "Madura Horseshoe". So far, typology studies of poverty in Indonesia use a single research method. The use of concurrent mixed methods is rarely done and even considered taboo in conventional research. The test results show that the method is very suitable to academic needs and very comprehensive in identifying the typology of poverty, particularly rampant poverty in an exclusive area with specific social structure and culture, namely those dominated by a particular ethnic group. The test concludes that the typology of poverty in the exclusive region of "Madura Horseshoe" is, in majority, a structural typology. The residents suffer from poverty because they do not have productive assets and social networks. Only a small percentage has cultural constraints, of which problems, including poverty, are solved by means of praying to God and asking blessings of sustenance. If this does not yield, they give up and resign to predestined fate.
\end{abstract}

Keywords: typology of poverty; poverty in Indonesia; mixed methods research; ethnic; social culture

\begin{abstract}
Abstrak
Artikel ini menjelaskan hasil tes, dengan menggunakan metode campuran secara bersamaan, untuk mengidentifikasi tipologi kemiskinan di salah satu daerah di Indonesia, khususnya di Provinsi Jawa Timur yang biasa disebut "Tapal Kuda Madura". Sejauh ini, studi tipologi kemiskinan di Indonesia menggunakan satu metode penelitian. Penggunaan metode campuran secara bersamaan jarang dilakukan dan bahkan dianggap tabu dalam penelitian konvensional. Hasil tes menunjukkan bahwa metode ini sangat tepat untuk kebutuhan akademis dan sangat komprehensif untuk mengidentifikasi tipologi kemiskinan, terutama kemiskinan yang merajalela di daerah eksklusif yang memiliki struktur sosial dan budaya yang spesifik seperti struktur sosial dan budaya yang didominasi oleh kelompok etnis tertentu. Simpulan dari uji metode campuran yang digunakan dalam kajian ini menunjukkan bahwa tipologi kemiskinan di wilayah eksklusif di Provinsi Jawa Timur, Indonesia pada daerah "Madura Horseshoe" adalah tipologi struktural. Mereka mengalami kemiskinan, karena mereka tidak memiliki aset produktif dan jaringan sosial. Ada pula kendala kultural, di mana masalah kemiskinan diatasi dengan cara berdoa kepada Allah SWT, agar diberkati dengan rejeki dan jika ini tidak berhasil, mereka pasrah dan menyerah pada takdir yang telah ditentukan.
\end{abstract}

Kata kunci: tipologi kemiskinan, kemiskinan di Indonesia, penelitian metode campuran; etnis; sosial budaya

\section{Introduction}

Poverty is still a crucial issue occuring in many countries in the developing countries (Guiga 2012; Meng et al. 200; Bourguignon 2003; Cobbinah et al. 2013; Todaro \& Smith 2006; Ashiomanedu 2008; Domfeh \& Bawole 2009; Fosu 2017; Adams 2004; Banks et al. 2017; Yuwinanto 2018). Various poverty alleviation programs has also been implemented by the Indonesian government but the results do not seem significant in reducing the poverty (Perdana \& Maxwell 2004; Sugandi 2016; Ariyani 2015; Purwanto 2007; Murdiyana \& Mulyana 2017; Budirahayu, 2018). As far now the results of the implementation of the program is more focused on reducing the number of poor households and efforts to let poor households survive, especially seen from their ability to meet the minimum daily needs (Rosfadhila 2011; Sulhan \& Sasongko 2017; Saptono 2013; Ariadi 2018). Though the shackle of poverty that they face is very complex, at least when viewed from the shackles of structure (e.g. very scarce productive network they have) and/or shackles of culture (e.g. very weak productive 
values they use as reference) (Jordan 2004; Adhi et al. 2016). Under such circumstances, it is reasonable that any poverty alleviation program implemented by any government, including the Indonesian government will not be able to touch the root of the real problem that led to widespread poverty in the region (Singgih 2009; Siahaan 2012; Sudarso 2018).

One of the factors that may cause poverty alleviation programs unable to touch the root of the real problem is the diagnosis of the problem which is less precise. Like a disease, poverty needs proper diagnosis so that treatment method conforms to the type, stage and prognosis of the disease. Efforts to make the diagnosis of diseases of poverty became an urgent necessity because the prognosis of the disease to be cured has structural and cultural dimensions. Therefore, diagnosis needs to use a comprehensive method such as a mixed method so that diagnosis results have accurate data, facts and information. What and how the results of the use of mixed methods is what to describe in this article, given that so far in the social sciences, especially sociology, the attempts to mix the two methods are still rare and still considered taboo even done in conventional research. Mixing new methods came into academic debate in the study of sociology in Indonesia especially when Tashakkori and Teddlie (1998) and Creswell (2009) introduced the method of mixing qualitative and quantitative research methods in a social study, although previously mixing method has been known through the methodological concept called triangulation (Denzin \& Lincoln 1997).

To identify poverty, the Indonesian government is still using a single method, which uses 14 (fourteen) indicators. The fourteen indicators are: area of home, type of home floor, type of home wall, facility for defecation, drinking water sources, lighting, fuel used, frequency of meals in a day, a habit of buying meat/chicken/milk, the ability to buy clothes, the ability for treatment in the health center/clinic, employment of household head, education of household head, and ownership of assets (Badan Pusat Statistik 2013). By using these fourteen indicators, what type of poverty experienced by the family cannot be identified (e.g. whether the family was experiencing poverty structurally or culturally). However, in reality, the poverty experienced by poor families may occur structurally, culturally or between them (Marianti \& Munawar 2006). Therefore it is necessary to use a mixture of methods (concurrent mixed methods) simultaneously, namely qualitative and quantitative methods. The method has been used to identify the spread of poverty in an exclusive area in the province of East Java, Indonesia, which is known as "Madura Horseshoe".

"Madura Horseshoe" is an area along the east to south coast of Madura island, which includes eleven counties. Called exclusive because throughout the region is dominated by ethnic Madurese which has a distinctive social network, system of values, and lifestyle. Hence, the poverty in the region is also very typical, in the sense of having significant differences with the widespread poverty in other parts of Indonesia. Test of mixed method was carried out in a sociological study, which results are expected not only to have internal validity but also external validity, so that it can represent typological problems of poverty in Indonesia or in other areas of the country that also has an exclusive territory. Moreover, the results of this study are also expected to correct the use of poverty indicators that only have a single method (objective), especially indicators which cannot identify what the typology of poverty experienced by poor households is.

Some indicators which are not able to identify the typology of poverty are such as an indicator of poor households' income per day, indicator of poor households calorie intake / person / day, indicator of the quality of life of poor households, indicator of consumption of rice / $\mathrm{kg} /$ poor household per month, the indicator of the welfare of poor households, and a variety of other indicators which use assumptions about the inability of poor households to make ends meet everyday. Hence, a comprehensive study is needed in observing poverty, especially in the two typologies. This becomes an interesting study because along with social and cultural changes occurring in society, typologies of poverty have also been expected to have changed and/or been changing, so that whatever government programs is implemented to reduce poverty, it should notice the real typology of poverty experienced by poor households. 


\section{Research Method}

As previously mentioned, the typology study of poverty in Indonesia so far only uses a single method. Thus, the concurrent use of mixed method proposed by Creswell (2009) is still rarely done and even considered taboo. Therefore, this study is to test that method. In brief, concurrent mixed method is a mixture between qualitative and quantitative research methods which are used at the same time in the research activities. Paradigmatically reviewed, the use of mixed method is a new breakthrough which, by some experts, is called a paradigmatic revolution because so far there is only single paradigm justified in sociological study. For example, researcher may use a paradigm of positivism, postpositivism, constructivism or critical only. Mixing paradigm is seen improper though Thomas Kuhn since decades ago, has explained the possibility of paradigm revolution, i.e. when the scientific paradigm believed as the truth experiences anomalies, the truth becomes questionable.

If this study only uses a single paradigm, it will obviously not be able to provide valid research results because the reality on the ground is not as simple as we imagine. Poverty has been measured objectively by using the size of an inability to meet daily needs. In fact, it is very dependent to who is experiencing the poverty. In other words, in addition to using a clear measure unit, poverty should be measured from the point of view of those who actually are experiencing real poverty. In certain ethnic neighborhoods, for example, they will understand poverty from their own perspective and not from the point of view of other ethnicities. The concept of poor, for example, is not realistic if it is imposed universally for all ethnic and social structures that have different cultures. All ethnicities in Indonesia by the hundreds will have its own concept of poverty. It means the concept of poverty in Indonesia which distinguishes rural and urban communities nationally that has clearly given rise to concept bias.

In the context of this study, to test concurrent mixed method used to identify the typology of poverty, two exclusive regions in East Java, Indonesia were chosen. They are commonly called the "Madura Horseshoe", i.e. Pamekasan and Probolinggo. The selection of these two districts is based on criteria of the number of poor households in the regions according to official data from the government. From each district, two sub-districts, which the number of poor households ranked first and second, were chosen. The number of respondents is specified to 100 poor households, in order to meet the statistical confidence level which is at least $95 \%$ of data and fault tolerance to a maximum of $10 \%$ of data.

To select respondents, the sampling technique used is like a snow ball rolling with the following criteria: First, the respondent belongs to the category of poor households seen from the view of social and economic (e.g., grooming, home state, and ownership of productive resources which visualize the poverty level). Second, respondents are beneficiaries of the government's poverty alleviation program in the current budget year. The sampling technique like a snow ball rolling is used with two methodological considerations. First, this research wants to capture the data, facts and information that is as rich and deep as possible of the number of poor households in an exclusive area in the province of East Java, Indonesia. Second, this study also wants to find shades of difference in the reality of how the poor perceive poverty based on their own experience, particularly of the respondents who had received assistance from the government's poverty alleviation program in the current budget year.

This study used three methods to collect data. First, field observation method using camera photos / videos; second, the method of structured interviews using questionnaires; and third, in-depth interviews using an interview guide. To perform visual field observations, camera is used to capture images and record video in order to catch standpoint really which visualizes the poverty level of the respondents. Meanwhile, interview was done by using a structured questionnaire containing variables and indicators of poverty, and in-depth interview guide was used for an interview. The interview contains points that describe the reality of subjective poverty.

All data were analyzed by using two methods of data analysis collaboratively. First, the quantitative data, which was analyzed by displaying the data in the form of frequency tables that describe the reality under study. The data were processed by using SPSS program and display table was converted into MS Word. And secondly, the qualitative data, which was analyzed by displaying the data in the 
form of narrative description texts that describe the reality under study. By using two models of the collaborative data analysis, it is expected to describe the reality of widespread poverty typologies in an exclusive area in a valid, reliable and current, particularly in the "Madura Horseshoe", East Java Province, Indonesia.

\section{Result and Discussion}

In order to identify the typology of poverty in the exclusive area, three indicators were used. First, ownership of productive assets, including education respondents have ever taken, the job of respondents to earn money, the type of job of the respondents, ownership/control of the respondent on the farm/fields, agricultural land/farm owned/dominated respondents, the type of crops grown on agricultural land/farm respondents have, and respondents ownership of cattle. Second, ownership of productive working relationship includes involvement of the respondents in the profit-sharing system in the cultivation of agricultural land/farm respondents and involvement in other forms of cooperation in the cultivation of land/farm. And third, the values becoming the reference of respondents in living their role in social and economic life which includes the values that form the basis of the respondents in pursuing life, doing work, and other values (eg, religious values and traditions) which form the basis for the respondent out of poverty.

All three indicators were used to identify the typology of poverty on the basis that: first, this study conceptually uses the concept of ownership of productive assets and productive working relationships, both socially and economically, to describe the reality of structural poverty. And second, using the concept of values enacting the reference of a family to work together productively to describe a productive culture of poverty, as theorized by Oscar Lewis in his concept of culture of poverty.

Based on the survey data from a number of poor households in the exclusive area, the conclusion of its typology is described as follows which includes two things. First, does the data indicate that poor households in the exclusive region actually experience structural poverty? And, second, on the other hand, does the data indicate that poor households in the exclusive area use a reference of culture of poverty? Dichotomy between structure and culture to describe the reality of poverty typologies was intentionally done because of the following two methodological considerations. First, in the study of sociology, there are two extreme types to identify the typology, namely typology (Type A) or typology (type B). Therefore, in this study, there is only poverty typology structurally or culturally poverty alone. And secondly, this study was only aimed at identifying the reality of the poverty of the two typologies. If the reality on the ground encountered "typology between", for example, poverty in the typology of structural and cultural - because of the relatively equal distribution of the indicators that a large percentage between them - it will be ignored.

The data used to identify the typology of poverty in the region of "Madura Horseshoe" is the data of education level taken by the respondents, the job of respondents to earn money, the type of job of the respondents to earn income, ownership/control over the respondents' agricultural land/fields, agricultural land/farm owned/dominated, the type of crops grown on agricultural land/farm respondents, respondents livestock ownership, type of government assistance received by the respondent, the form of mutual help in the cultivation of agricultural land/farm in the village, how cultivation of agricultural land/farm owned by the rich, the use of certain values by respondents in real life, the use of religious values by respondents in real life, the use of traditional values in real life.

By looking at the high percentage of the data obtained, typology of poverty spread in the region can be identified. In a sociological study of typology in general percentage is used to perform analysis so that interpretation can be drawn. That is, if the data showed the largest percentage in a certain typology, that typology is the conclusion. In this case, the largest percentage should not be counted for over $50 \%$ of the total sample, but calculated from the largest or most nominal sample size which may not be above 50\%. Therefore, the typological analysis often does not reveal any absolute typology, which describes a reality. For example, in a typology, particular variables which are also found in other typologies may appear. In other words, if a typology of structural poverty found in this study, the 
reality does not mean that in a society cultural variables are not found. These variables are variables that are used to describe the reality of poverty where each typology can be accommodated. In structural poverty, for example, of course you will also find cultural variables; and vice versa, in the culture of poverty, structural variables will also be found.

After analyzing the data, it appears that the typology of poverty which is rampant in the "Madura Horseshoe" region is a structural poverty. The typological reality looks at the three main variables that are used to perform identification of typology of poverty, namely: education level, employment and ownership/control of productive land. Based on the data of education level taken by the respondents, both Probolinggo and Pamekasan have equally low education or completed elementary school only. Respondents in Pamekasan who only completed primary school are as much as $38 \%$, and as much as $36 \%$ in Probolinggo. Moreover, the reality of the typology is also evident from the job of the respondents. The data show that the majority of respondents working any job in Pamekasan to earn money is as much as $28 \%$, and working as farm laborers as much as $20 \%$. In Probolinggo, the majority job as farm laborers is as much as $32 \%$, and working any job is as much as $14 \%$. In addition, the typology of structural poverty in the region also looks strikingly from data of ownership/control of agricultural land/farm. The data show that the majority of respondents in Pamekasan as much as $90 \%$ do not have/master agricultural land/farm, and respondents in Probolinggo also the majority (64\%) do not have/master agricultural land/farm.

When examined theoretically and empirically, the three main variables that are used to identify a typology - namely education level, occupation and ownership of productive land - it is a potential major resource that can provide income (money) directly to the owner. In other words, although there are other variables that also theoretically and empirically could be the yardsticks for identifying rampant typologies of poverty, these variables are actually just a "follow-up variable". For example, variables of the area of agricultural land/farm owned, the type of crops grown, planted crops, livestock ownership and a variety of other variables that the economic dimension, which until now are relevant to measure the level of income.

In addition to using objective indicators, this study also uses subjective indicators. These indicators will be the "new indicator" in the study about the typology of poverty in Indonesia. They are used for in-depth interviews with respondents and accompanied by visual data relating to the respondents' understanding. Keywords in the exploration of the data is "understanding", i.e. the understanding of the poor regarding to the poverty they experience, the understanding of the poor regarding to the availability of their food, the understanding of the poor regarding to how proper the clothes they wear, the understanding of the poor regarding to the state of homes they occupy, the understanding of the poor regarding to job they do every day, the understanding of the poor regarding to the condition of his health, the understanding of the poor regarding to the life expectancy they have, the understanding of the poor regarding to the limitations of their education level, the understanding of the poor regarding to the limitations of their skills, the understanding of the poor regarding to the limitations of their capital, the poor understanding of the understanding of the poor regarding to the scarcity of productive resources, and the understanding of the poor regarding to changing their fate as the poor.

\section{Conclusion}

The conclusion of the test of concurrent mixed method used in this study: first, the typology of poverty in the exclusive region in East Java Province, Indonesia in the "Madura Horseshoe" is structural typology in majority. They suffer from poverty, because they do not have productive assets and networks, for example, they do not have/master productive agricultural land/farm, do not have a regular job, do not have the capital, unskilled labor and no productive working relationship in the form of gainsharing. In order to overcome their poverty moment, they establish social relationships with other people who are considered more capable to provide assistance (e.g., a relationship with people who are willing to lend money and/or willing to give jobs). Only a small percentage has cultural constraints, which is solved by means of praying to God Almighty, to be blessed with sustenance and if this does not work, they are resigned to the destiny that has been doomed. 
Based on the results of the test of concurrent mixed method as described earlier, the research team recommends to the parties not to use a single method to identify the typology of poverty, especially poverty which is rampant in an exclusive area. Every country has exclusive territories - which due to various reasons, the population experiences poverty in the region. Currently, the use of mixed methods concurrent becomes a necessity because the actual reality of poverty could only be understood by those who actually experience poverty. By using the analogy that poverty is a chronic disease that requires proper treatment, the data collection of typology of poverty is an attempt to diagnose their illnesses - and thus - disease therapy performed by the parties can be more effective.

Therefore, to raise poor households experiencing structural poverty, efforts should be conducted with regard to the provision, improvement or enhancement of their productive assets both in the social and economic assets, so that the poor experiencing structural poverty can use actual structural assets available for them. Meanwhile, to raise poor households whose poverty is due to the use of specific cultural values, efforts should be conducted with regard to the generation, improvement or enhancement of their productive spirit, so that households experiencing poverty can use that productive spirit to overcome their poverty.

\section{References}

Adams RH (2004) Economic growth, inquality and proverty: estimating the growth of poverty. World Development 32 (12):1989-2014.

Adhi MK, Ardana IK, \& Maduriana IM (2016) faktor penyebab kemiskinan kultural dan model pengentasan berbasis kearifan lokal: Studi pada masyarakat miskin di Pegunungan Kintamani, Bali. Jurnal Kajian Bali 6 (2):229-246.

Ariadi S (2018) Optimalisasi program dan kegiatan Corporate Social Responsibility di Kota Bontang. Jurnal Sosiologi Dialektika 13 (1):31-47.

Ariyani N, Fauzi A, Juanda B, \& Beik IS (2015) Evaluasi pogram pengentasan kemiskinan menggunakan metode rappoverty. Jurnal Ekonomi \& Kebijakan Publik 6 (2):181-197.

Ashiomanedu J (2008) Poverty and sustainable development in the Niger delta region of Nigeria. Journal of Sustainable Development in Africa 10 (3):155-171.

Badan Pusat Statistik (2013) Profil Kemiskinan di Indonesia Maret 2013. Jakarta: Badan Pusat Statistik.

Banks LM, Kuper H, \& Polack S (2017) Poverty and disability in low- and middleincome csountries: A systematic review. Plos One 12 (12):1-19.

Bourguignon F (2003) The poverty-growth-inquality triangle. In: Indian Council for Research on International Economic Relation, New Delhi, India.

Budirahayu T (2018) Perkembangan koperasi di Jawa Timur. Jurnal Sosiologi Dialektika 13 (1):88-95.

Cobbinah PB, Black R, Thwaites R (2013) Dynamics of poverty in developing countries: Review of poverty reduction approaches. Journal of Sustainable Development 6 (9):25 - 35 .

Creswell JW (2009) Research Design: Qualitative, Quantitative and Mixed Methods Approaches. California, Thousand: Sage Publications.

Denzin NK \& Lincoln YS et al (1997) Handbook of Qualitative Research. California: Sage Publication.

Domfeh KA \& Bawole JN (2009) Localizing and sustaining poverty reduction: experiences from Ghana. International Journal of Management of Environmental Quality 20 (5):490-505.

Fosu AK (2017) Growth, inequality, and poverty reduction in developing countries: Recent global evidence. Research in Economics 71 (2):306 - 336.

Guiga H (2012) Poverty, growth and inequality in developing countries. International Journal of Economics and Financial Issues. International Journal of Economics and Financial Issues 2 (4): $470-479$.

Jordan G (2004) The causes of poverty cultural vs structural: Can there be a synthesis? Spring 14:1834. 
Marianti R \& Munawar W (2006) Moving Out of Poverty: The Case of Desa Branta Pesisir, Kabupaten Pamekasan. Jakarta: SMERU Research Institute.

Meng X, Gregory R, \& Wang Y (2005) Proverty, inquality and growth in urban china. Joural of Comparative Economics 33 (4):710 - 729.

Murdiyana \& Mulyana (2017) Analisis kebijakan pengentasan kemiskinan di Indonesia. Jurnal Politik Pemerintahan 10 (1):73-96.

Perdana AA \& Maxwell J (2004) Poverty Targeting in Indonesia: Programs, Problems and Lessons Learned. In: Centre for Strategic and International Studies Economic Working Paper Series, Jakarta, Indonesia.

Purwanto EA (2007) Mengkaji potensi usaha kecil dan menengah (UKM) untuk pembuatan kebijakan anti kemiskinan di Indonesia. Jurnal Ilmu Sosial dan Ilmu Politik 10 (3):295-324.

Rosfadhila M, Toyamah N, Sulaksono B, Devina S, Sodo RJ, \& Syukuri M (2011) Kajian Cepat Pelaksanaan Program Bantuan Langsung Tunai (BLT) 2008 dan Evaluasi Penerimaan Program BLT 2005 di Indonesia. Jakarta: SMERU Research Institute.

Saptono A (2013) Evaluasi Program pengentasan kemiskinan (studi kasus pemberdayaan ekonomi pada Program Nasional Pemberdayaan Masyarakat Mandiri perkotan di Kelurahan Perwira Kecamatan Bekasi Utara Kotas Bekasi Jawa Barat. Econosains 11 (2):29-54.

Siahaan H (2012) Kemiskinan, Kesenjangan dan Keadilan: Sudahkah Pembangunan Benar-benar ProRakyat? Surabaya: Departemen Sosiologi FISIP Unair.

Singgih DS (2009) Kemiskinan dan Implementasi Kebijakan Pro-Poor di Jawa Timur. Surabaya: Dewan Pakar Provinsi Jawa Timur.

Sudarso (2018) Kebijakan exit strategy mengatasi kenaikan harga BBM. Jurnal Sosiologi Dialektika $13(1): 18-30$.

Sugandi YS (2016) Program penanggulangan kemiskinan perkotaan: Pengalaman Kota Bandung. Jurnal Analisis dan Pelayanan Publik 2 (1):109-128.

Sulhan M \& Sasongko T (2017) Implementasi kebijakan program penanggulangan kemiskinan melalui Kartu Penjamin Soial dan Kartu Indonesia Pintar pada masyarakat. Jurnal Ilmu Sosial dan Ilmu Politik 6 (1):15-18.

Tashakkori A \& Teddlie C (1998). Mixed Methodology: Combining Qualitative and Quantitative Approaches. Thousand Oaks California: Sage Publications.

Todaro PM \& Smith SC (2006) Economic Development. Washington DC: Pearson Education Harlow.

Yuwinanto HP (2018) Pelatihan keterampilan dan upaya pengembangan UMKM di Jawa Timur. Jurnal Sosiologi Dialektika 13 (1):79-87. 